\title{
Arabic Poetry as Teaching Material in Early Modern Grammars and Textbooks*
}

\author{
Jan Loop
}

Excerpts of Christian texts and of the Qur'an were not the only texts with which the early modern students of Arabic could exercise the grammatical rules of the language. From the very beginning, Arabic poetry played an important role as a literary genre that was esteemed to be of central cultural importance to the Arabs and thus deserved a special place in the teaching and learning of their language. Hence, it was in textbooks and grammars that European scholars first printed specimens of Arabic poetry, together with accounts of the system of Arabic prosody. Usually these editions were equipped with detailed grammatical, syntactical, semantic and metrical comments, while questions of historical circumstances, of cultural functions and poetical traditions were only occasionally discussed. Based on an analysis of published textbooks and grammars, the following essay gives a survey of the first European encounters with Arabic poetry and it assesses its significance for the teaching and learning of Arabic.

As with Arabic literature and culture in general, the seventeenth century also witnessed a new interest in Arabic poetry. We find a testimony to this new appreciation of the Arabic poetical heritage in Thomas Erpenius's famous Oration on the Value of the Arabic Language, held in Leiden in 1620:

There are not in the rest of the world nor were there ever, as many poets as in Arabia alone. I am not lying, dear listeners. They number sixty poets

* I have presented a first draft of this paper in March 2011 at Christopher Ligota's seminar The History of Scholarship and I read revised versions at the conference Poetics and Knowledge in Early Modern Europe, Merton College, Oxford, 23 May 2013 and at the workshop Arab Culture and the European Renaissance, New York University, Abu Dhabi, 14-15 April 2013. I would like to thank Alastair Hamilton who has corrected and improved style and content of the piece and to Arnoud Vrolijk and Charles Burnett for reading and commenting on earlier drafts. 
of the first rank, who have several squadrons under them, and in whose writings there is such elegance of invention, as well as learning, care in composition, and sweetness in harmony and rhythm that anyone who reads or hears them is totally carried away by their charm. Thus it is not surprising that Leo Africanus and other authors say that Arabic poetry is such an incredible delight that there is nothing in other languages that can be compared to it. Shortly, dear listeners, you will be able to read the greatest of all poets the world has ever seen, whom they call al-Mutanabbì, as if to say, the Prophesier. ${ }^{1}$

The reference in this passage is to one of the several eloges to Arabic poetry in Leo Africanus' Description of Africa, most probably to his account at the very beginning of the work. ${ }^{2}$ But it is with Erpenius that the topos that Arabic is the most beautiful language in the world and that the poetry written in it surpasses all the others in beauty, harmony and sublimity, found its way from the East to the West. The idea that Arabia is the place where the best poets the world has ever seen perform their art in the most beautiful of all languages is not only an argument of cultural pride; it also plays a pivotal role in the most central Islamic dogma of the inimitable beauty of the Qur'an. ${ }^{3}$ For the dogma, in its classical form, argues that Muhammad, who was an illiterate, uneducated

1 'Poetas non tot habet, aut habuit unquam reliquus orbis, quot sola Arabia. Non mentior, Auditores, numerant illi sexaginta Poetarum principes, qui sub se habent aliquot turmas: in quorum scriptis tanta est inventionis elegantia, atque eruditio, compositionis accuratio, harmoniae et Rhythmi suavitas, ut qui ea legit, auditve, dulcedine eorum totus abripiatur. Unde mirum non est, Leonem Africanum, aliosque Auctores dicere, Incredibilem esse poëseos Arabicae suavitatem, \& tantam ut cum ea nihil in reliquis linguis comparari possit. Ego operam dabo, Auditores, ut re ipsa hoc edoceamini; \& ut habeatis brevi Principem omnium Poëtarum quos unquam vidit mundus, quem Mutenabbi, illi vocant, ac si Prophetantem dicamus.' T. Erpenius, Orationes tres de linguarum Ebraeae, atque Arabicae, dignitate, Leiden, 1621, pp. 59-6o. I follow Robert Jones' translation in 'Thomas Erpenius (1584-1624) on the Value of the Arabic Language', Manuscripts of the Middle East, 1, 1986, pp. 15-25 (19).

2 'They take great delight in poetrie, and will pen most excellent verses, their language being very pure and elegant. If any woorthie poet be found among them, he is accepted by their governours with great honour and liberalitie; neither would any man easily beleeue what wit and decensie is in their verses.' Description of Africa, trans. J. Pory (160o), ed. R. Browne, London, 1896,158 . This passage is also quoted by other European Orientalists, see below fn 65 .

3 On this dogma and its significance see the book by N. Kermani, God is Beautiful. The Aesthetic Experience of the Quran, Cambridge, 2015. On its reception in the West, see my 'Divine Poetry? Early Modern European Orientalists on the Beauty of the Qur'an', Church History and Religious Culture, 89.4, 2009, pp. 455-88. 
man, produced a Qur'an with which, the great Arabic scholar al-Tabarī said, 'he challenged a people at a time when they were acknowledged masters of the art of rhetoric, poetry and rhymed prose.' Muhammad told them, al-Ṭabarī continues, 'that they were incapable of bringing anything comparable to even a part of what he had brought, and indeed, they lacked the power to do this.' The belief, in other words, that this illiterate and uneducated man, surrounded by the greatest masters of poetry, spoke a language that none of these poets was able to imitate and surpass, is the central proof of the divine origin of the Qur'an. It is seen as 'the counterpart to the raising of the dead and the curing of lepers and the blind. 5 So, the exceptional beauty of Arabic poetry plays a most central role in Islamic theology and apology and Erpenius, in his oration on the Arabic language at the beginning of the seventeenth century, transmitted this notion to Europe.

The Qur'an's key role as a grammatical and linguistic norm of Arabic had been recognized by European scholars very early on. Excerpts from the Qur'an were thus considered essential texts for the student to acquire an adequate knowledge of the language and can be found in many of the Arabic chrestomathies published in early modern Europe. ${ }^{6}$ In 1617 , Thomas Erpenius himself edited two suras from the Qur'an - the Sürat Yüsuf and al-Fätiha - for students of Arabic to practice what they had learned from his Arabic grammar. ${ }^{7}$ In the shorter version of his grammar, the Rudimenta linguae Arabicae (1620), Erpenius advised his students to read repeatedly the text of the Qur'an and to assess it with the grammatical rules provided. To facilitate this praxis, he edited another excerpt from the Qur'an, sura 64 (al-Taghābun), together with a literal word-by-word translation into Latin and a grammatical analysis in the appendix of the book.

But for the study of the Arabic language and for an adequate understanding of its literature and culture, it was imperative for the student to also become acquainted with the genre in which the Arabs excelled all other nations; poetry. Hence, Erpenius was toying with the idea of editing the work of the most famous Arabic poet, Abū l-Ṭayyib Aḥmad b. al-Ḥusayn al-Mutanabbīi. ${ }^{8}$ His premature death four years after giving the lecture prevented him from

4 The Commentary on the Qur'ān by Abü Ja'far Muhammad b. Jarīr aț-Tabarī. Being an abridged translation of Jāmi' al-bayān 'an ta'wīl āya al-Qur'ān, eds W.F. Madelung and A. Jones, trans.

J. Cooper, vol. 1, Oxford, 1987, pp. 10-11.

5 Ibid., p. 10.

6 See Alastair Hamilton's article in this collection.

7 T. Erpenius, Historia Josephi Patriarchae, Leiden, 1617.

8 On al-Mutanabbī see A.J. Arberry, Poems of al-Mutanabbī. A Selection with Introduction, Translation and Notes, Cambridge, 1967. 
carrying out this project and it was not until 1765 that Europe saw the publication of a substantial number of verses by al-Mutanabbī in Johann Jacob Reiske's Proben der Arabischen Dichtkunst in verliebten und traurigen Gedichten aus dem Motanabbi. Arabisch und Deutsch nebst Anmerkungen, which were affectionately dedicated to his wife Ernestine Christine. ${ }^{9}$ The edition was based on his transcription and the translation of al-Mutanabbī's Dīwān from a Warner manuscript for which he tried in vain to find a publisher. ${ }^{10}$

Erpenius' project to provide students of Arabic with text material taken from the enormous funds of Arabic poetry was carried out by his most distinguished pupil, Jacobus Golius, who, in 1618, registered at the University of Leiden to study Arabic. After Erpenius's early death in 1624, Golius succeeded him in the chair of Arabic and from the very beginning of his career showed a particular interest in poetry. Golius's very first publication was at the same time the first instance of any work of Arabic poetry being put into print. The anonymously published book, which, apart from the title page, is printed entirely in Arabic types, without any Latin commentary or translation, appeared in 1629 on the Elzevier printing press in Leiden. Intended as a textbook, this publication seems to have been widely used for teaching purposes, for example by Golius's student Johann Fabricius in Rostock and by Edward Pococke in his early years as a professor of Arabic at Oxford.11 The book offered a characteristic selection of fully vocalized texts for the tyrones to practice the grammatical rules of the Arabic language, a collection of Arabic proverbs, a khutba by Ibn Sina, a number of sentences from different poets -among them also verses by al-Mutanabbī -and a homily on the birth of Christ by Eliya III (Abū Halīm Ilìyā al-Hadìthī), Catholicos of the Nestorian Church between 1176 and $1190 .{ }^{12}$ The jewel of the book was a poem called Lämiyyat al-'ajam by a

$9 \quad$ Proben der Arabischen Dichtkunst in verliebten und traurigen Gedichten aus dem Motanabbi. Arabisch und Deutsch nebst Anmerkungen, Leipzig, 1765. The occasion of the publication was the thirtieth birthday of his wife, Ernestine Christine, whom he had married the year before. The publication provoked a sarcastic review in the Göttingische Anzeigen von gelehrten Sachen, 1765 , pp. 465-71.

J.J. Reiske, Von ihm selbst aufgesetzte Lebensbeschreibung, Leipzig, 1783, p. 163. There are prints of a few verses by al-Mutanabbī in one of Erpenius's outstanding contributions to Oriental scholarship, his edition of al-Makin's Ta'rīkh al-Musliminn, the Historia Saracenica. Some additional verses by al-Mutanabbī were also published by Jacobus Golius.

11 See below.

12 Based on LUL, MS Or. 170; see J.J. Witkam, Inventory of the Oriental Manuscripts of the Library of the University of Leiden, vol. 1, Leiden, 2007, p. 74. This manuscript was also copied by Hottinger, see Jan Loop, Johann Heinrich Hottinger. Arabic and Islamic Studies in the Seventeenth Century, Oxford, 2013, p. 150. 
Persian-born poet known as al-Husayn b. 'Alī al-Ṭughrā'ì. ${ }^{13}$ The poem of the nonArabs, rhyming in $L$ is a qasida in fifty-nine stanzas, each of them ending in the same letter, -lam. It is named after the famous Lamiyyat al-arab - The poem of the Arabs, rhyming in $L$ - attributed to the pre-Islamic poet al-Shanfarā, to which it has some superficial similarities. Al-Shanfaräs Lämiyyat al-arab is recognized as one of the greatest of all Arabic poems and a celebrated example of pre-Islamic șu 'ūk poetry. ${ }^{14}$ In contrast to al-Shanfarā, al-Ṭughrāì seems to have been well integrated in the eleventh- and twelfth-century urban society in which he lived. Information about his biography and his personality circulated early in Europe thanks to an entry in Leo Africanus's De viris quibusdam illustribus apud Arabes, first published by Johann Heinrich Hottinger in his Bibliothecarius Quadripartitus. ${ }^{15}$ Here, the European reader could learn about al-Ṭghrâ̄î's alchemical work and his wealth. ${ }^{16}$ Whether, however, al-Ṭughrāī was such an avaricious and embittered man as Leo Africanus makes us believe, is doubtful, but the poem on which al-Ṭughrāis's reputation rests, is indeed a bitter lamentation about the evil times in which he lives and his ill-treatment at the hands of his contemporaries. It was written in Baghdad in 1111-2 and became famous immediately for its beauty, depth and rich vocabulary and it led to the composition of a number of commentaries. ${ }^{17}$ Although it was written by a twelfth-century civil servant, it retains the literary conventions of early Arabic poetry and abounds in 'heavy and rather Pharisaical moralizing. ${ }^{18}$ The sententious morality of the poem was certainly one of the reasons for the enormous popularity it held among European Orientalists in the seventeenth and eighteenth centuries.

Golius's 1629-edition of the Lämiyyat al-ajam marks the beginning of a long series of publications of this poem, many of which are milestones in the history of Arabic philology and scholarship. ${ }^{19}$ In 1661, based on the Arabic text

13 Hoc est Proverbia quaedam Alis, Imperatoris Muslimici, et Carmen Togra”̈, Poëtae doctiss., nec non Dissertatio quaedam Aben Sinae, ed. J. Golius, Leiden, 1629.

14 On this genre of poems, composed by men who had become outcasts of their tribe, see A. Jones, Early Arabic Poetry, vol. ı: Marāthī and Șu 'ūk Poems, Oxford, 1992.

15 J.H. Hottinger, Bibliothecarius Quadripartitus, Zurich, 1664, pp. 265-7.

16 On his alchemic works see M. Ullmann, Die Natur- und Geheimwissenschaften im Islam, Leiden, 1972, pp. 229-31.

F. Rosenthal, 'Blurbs (taqrîz) from Fourteenth-Century Egypt', Oriens, 27/28, 1981, pp. 177-96 (179).

18 P.M. Holt, Arabic Studies in Seventeenth-Century England, with Special Reference to the Life and World of Edward Pococke. B.Phil thesis, Oxford, 1952 (MS. M.Litt. c.15), p. 65. with Golius's Latin translation, which had been provided by his friend Adriaen Reland. Cf. 
of Golius's edition, ${ }^{20}$ Edward Pococke published his commented bilingual Arabic-Latin edition, together with a groundbreaking essay, De Prosodia Arabica, by his student Samuel Clarke. ${ }^{21}$ Johann Jacob Reiske's edition Thograi's sogenanntes lammisches Gedichte - was prefaced by an interesting Short Sketch of Arabic Poetry (Ein kurtzer Entwurff der Arabischen Dichterey), in which Reiske proposed to apply the principles, which Robert Lowth had developed in his lectures on the Sacred Poetry of the Hebrews, to Arabic poetry. ${ }^{22}$ Reiske's Sketch was too short and his interest in Arabic poetry not great enough to embark on this enormous task. It was left to the young William Jones to follow this advice twenty years later in his Poeseos Asiaticae commentariorum libri sex, which appeared in London in 1774. Not only did the entire appearance of this book, its title and the title page closely follow Robert Lowth, but so did its composition and the Latin terminology. Above all, it was Robert Lowth's discovery of an energetic 'language of passion' as characteristic of poetry in general which was decisive for William Jones's own concept of poetry and his appreciation of the Eastern taste. ${ }^{23}$

In 1758, two years after Reiske's German translation of the text, Leonard Chapelow presented a free translation of the Lämiyyat al-ajam into English

Poema Tograi, cum Versione Latina, Jacobi Golii, hactenus inedita. Quam ex Msto Goliano praefatione, \& notis quibusdam auctam edidit Matthias Anchersen, Utrecht, 1707, pp. A4 ${ }^{\mathrm{v}}$ $\mathrm{B}^{\mathrm{r}}$. Another Latin-Arabic edition, based on Golius's translation, was published by Henrik van der Sloot, Franeker, 1769. Another German translation appeared as 'Eine arabische Elegie' in the journal Neuer Teutscher Merkur, 1, 1800, pp. 8-18. This free translation in distichs was apparently produced by the poet and translator Karl Ludwig von Knebel, cf. Anke Bosse, Meine Schatzkammer füllt sich täglich, Göttingen, 1999, p. 505.

See A. Vrolijk, Arabic Studies in the Netherlands: A Short History in Portraits, 1580-1950, Leiden et al., 2014, p. 46.

Pococke's translation was reprinted by J.F. Hirt in his Anthologia Arabica complexum variorum textuum Arabicorum selectorum, partim ineditorum, sistens. Adiectae sunt versio Latina et adnotationes, Jena, 1774, pp. 119-74 and partly in his Institutiones arabicae linguae, Jena, 1770 .

Thograi's sogenanntes Lammisches Gedichte aus dem Arabischen übersetzt nebst einem kurtzen Entwurff der Arabischen Dichterey, Friedrichstadt, 1756. This publication is very rare; we know that only one hundred copies were printed.

23 See my ,Language of Paradise: Protestant Oriental Scholarship and the Discovery of Arabic Poetry', in Faith and History: Confessionalisation and Erudition in Early Modern Europe, eds N. Hardy and D. Levitin, forthcoming in the Proceedings of the British Academy series. 
based on Pococke's Latin translation rather than the original Arabic. ${ }^{24} \mathrm{He}$ chose the title The Traveller and he tried to render the metrical structure and quality of the poem (bāsiț) by using the iambic metre. He did not, however, attempt to imitate the characteristic rhyme scheme. Before that, in 166o, the French physician and Orientalist Pierre Vattier had already rendered Golius's entire 1629 edition into French, including L'Elegie du Tograï. ${ }^{25}$ What is notable about this publication is the fact that it contained the first vernacular treatise on Arabic metrics, a thirty-five page long Traité de la prosodie Arabique. Whereas the translation of al-Tughrāî's poem was entirely based on Golius's edition, Pierre Vattier's treatise on Arabic prosody was merely a summary of Filipo Guadagnoli's De arte metrica. Guadagnoli inserted this treatise of the classical Arabic system of metrics into his Arabic grammar, the Breves arabicae linguae institutiones. ${ }^{26}$ This was done in a remarkable manner, for he presented this classical theory with the help of a famous Arabic didactic poem, the so-called Qașida al-Khazrajiyya. ${ }^{27}$ Guadagnoli printed the verses of the poem, translated them, commented on them in detail and inserted numerous examples of Arabic poetry in order to illustrate the complicated system of Arabic prosody. ${ }^{28}$ He also included Arabic - Latin versions of a number of poems ascribed to 'Alī b. Abī Țālib, some of which reappeared a century later in the work of a Dutch scholar, Gerardus Kuyper. ${ }^{29}$ Whether Guadagnoli's students and his readers were in fact able to make good use of his chapter on metrics remains doubtful. Although his translation of the Qașida al-Khazrajiyya was accompanied by illustrative examples and additional comments from al-Damāmīnīs commentary and from Fīrūzābādī's Qāmūs al-muhiṭ (a work on which Guadagnoli relied heavily in composing his grammar), ${ }^{30}$ much of its content remained

24 L. Chappelow, The Traveller: an Arabic Poem, intitled Togral, written by Abu-Ismael; translated into Latin, ... with notes in 1661, by E. Pocock ... Now rendered into English in the same iambic measure as the original; with some additional notes, ... Cambridge, 1758. See P.M. Holt, Studies in the History of the Near East, London, 1973, p. 17.

25 P. Vattier, L'Elegie du Tograi, avec quelques sentences tirées des Poëtes Arabes, l'Hymne d'Avicenne, \& les Proverbes du Chalife Gali. Le tout nouvellement traduit de l'Arabe, Paris, 1660.

26 F. Guadagnoli, Breves Arabicae linguae institutiones, Rome, 1642, p. 283.

27 The extracts are all identified and critically assessed by R. Basset, Le Khazradjyah, Algiers, 1902, passim; on al-Damāmīnī, see p. ix.

28 Guadagnoli left out verses $5^{2-79}$, which deal with 15 metres from țawül to mutaqārib. He also did not print the last verses $95^{-6}$.

29 Gerardus Kuypers, Ali Ben Abi Taleb Carmina, Leiden, 1645.

30 In the 1632 edition by A. Giggeius, Kanzu al-lughati al-'arabiyyati sive Thesaurus linguae arabicae, Milan, 1632. See also A. Girard, 'Des manuels de langue entre mission 
obscure, even for Guadagnoli himself, who repeatedly expressed his lack of understanding of certain passages. ${ }^{31}$ Still, his introduction to the system of Arabic metrics was widely read; in addition to Pierre Vattier's French translation it found its way into another Italian grammar, the Flores grammaticales Arabici idiomatis by Agapito à Valle Flemmarum, published in Padua in $1687 .^{32}$ It was not, however, the first account of Arabic prosody to be printed in early modern Europe, as is often assumed..$^{33}$ Guadagnoli was preceded by a German pioneer of Arabic studies, Johann Fabricius of Danzig. ${ }^{34}$

Johann Fabricius was a curious man whose life and work bring us back to Jacobus Golius. He was one of the many young German students who left their devastated country during the Thirty Years' War to study Arabic with Golius in Leiden. ${ }^{35}$ In 1635 Fabricius eventually returned to Germany and started giving private Arabic lessons in Rostock. However, he seems not to have been able to find an appointment in Rostock and finally returned to his hometown Danzig, where he acted as a pastor and scholar and where he died in 1653 .

Fabricius's stay in Rostock was short, but he still left a mark there, primarily by instigating the printing house of Johann Richel to equip itself with Arabic types made in Copenhagen after the model of the Erpenius types. The scholars of Rostock celebrated this acquisition with a number of poems and congratu-

et érudition orientaliste au XVII ${ }^{\mathrm{e}}$ siècle: les grammaires de l'arabe des Caracciolini' in L'Ordine dei Chierici Regolari Minori (Caracciolini): religione e cultura in età postridentina, special issue Studi medievali e moderni, eds I. Fosi and G. Pizzorusso, 14-1, 2010, pp. 27996 (289).

See, for example, his comments on the obscurity of the passage on p. 300 and his explicit struggles in understanding it. See also Basset, La Khazradjyah, p. viii. See Schnurrer, Bibliotheca Arabica, no. 85, pp. 59-6o.

See for instance D. Frolov, Classical Arabic Verse. History and Theory of 'Arūd, Leiden, 2000.

34 I am omitting the treatise on the metrics of Arabic poetry (De arte metrica) by Leo Africanus as it seems only to have existed in manuscript form and was known only to a very small circle of scholars. See the edition by A. Codazzi, who discovered the manuscript in her 'Il trattato dell'arte metrica de Giovanni Leone Africano', in Studi orientalistici in onore di Giorgio Levi della Vida, vol. I, Rome, 1956, pp. 180-98.

For a short outline of Fabricius' life and work see Ephraim Praetorius, Athenae Gedanenses ... Leipzig, 1708, pp. 96-7. 
latory publications. ${ }^{36}$ It was with Avicenna's Qașida al-nafsìya or al-'aynīya, the Ode on the Human Soul that the printer Johannes Richelius inaugurated the new Arabic types on 16 October $1636 .{ }^{37}$ This is the very first publication of a popular poem, which has sparked many commentaries and which figured in a number of anthologies in Arabic textbooks of the Ottoman period. ${ }^{38}$

A few months later, on 14 February 1637, Fabricius had another specimen printed with the Richelius types. It was the Arabic text of a poem taken from the Dīwān of the mystic Manșūr al-Hallāj, on the occasion of Johannes Raue's appointment as professor of Rhetoric in Rostock. ${ }^{39}$ The distich by Manșūr is followed by a longer poem of twelve verses which are of different form and metre and end in -al (while Manșūr's verses end in -āl). ${ }^{40}$ Also in content, the two poems are completely unconnected. Manșūr al-Ḥallāj describes the mystical union of two spirits, whereas the second part laments the destruction brought by war and praises God as a source of salvation.

I was not able to discover where Fabricius had taken these poems from. al-Hallāj's poem seems not to have been copied from the Historia Saracenica where it was first printed and translated by Erpenius. There, in the context of the reign of al-Muqtadir, al-Makīn mentions the execution of Manșūr al-Hallāj and added a number of verses from his Diwānn, among them this beautiful distich. ${ }^{41}$ The variants to Fabricius' edition, however, suggest that he was in possession of a copy of his own.

36 Typographia Arabica Nova, de qua M. Johanni Fabricio Dantis... Et Richeliis haeredibus ... gratulati olim sunt ... Professores, Doctores, Magistri, et Amici Carminibus, jam demum publicae luci expositis a Johanne Klein. Typis Viduae Georgii Rhetii, 1652. Unfortunately, I have not yet seen the collection of poems from Fabricius's colleagues, which seems to have only survived in a copy at the University Library, Gdansk.

The British Library preserves a copy of this rare specimen, under the shelfmark 837 h.15, $632^{*}$.

38 D. de Smet, 'Avicenne et l'ismaélisme post-fatimide selon la risāla al-mufída fì ịdāh mulġaz al-qașìda de 'Alī b. Muhammad b. al-Walīd' in Avicenna and his Heritage. Acts of the International Colloquium, eds J. Janssens and D. de Smet, Leuven, 2002, pp. 1-20. For an English translation see A.J. Arberry, Avicenna on Theology, London, 1951, pp 77-8.

This rare print too can be found at the British Library, shelfmark 837 h.15, 6. The poem is printed and translated in L. Massignon, Le Dîwân d'Al-Hallâj, Paris, 1955, M. $\mathrm{N}^{\circ}$ 47, pp. 81-82. Apart from Massignon's pioneering work on al-Hallāj, see also A. Schimmel, Mystical Dimensions of Islam, Chapel Hill, 1975, pp. 62-77 and H.W. Mason, Al-Hallaj, Richmond Surry, 1995 .

40 I would like to thank Professor Carl W. Ernst (Chapel Hill) for his help in translating and interpreting this curious poem edited by Fabricius.

41 Historia Saracenica (Lat. Arab. ed.), Leiden, 1625, p. 188-9. The poems are printed and translated in Massignon, Le Dîwân d'Al-Hallâj, M. N 47 , pp. 81-2, M.N. 5, pp. 40-41. 
Apart from these occasional publications, the most important work to be printed with the Richelius-types is Fabricius's own Specimen arabicum, which 'exhibits', as the subtitle has it, 'Arabic works, some in Prose and some in Verse'.42 Although the book is a fascinating testimony to the spread of the interest in the language and culture of the Arabs deep into the provinces of Protestant Germany in the mid-seventeenth century, it has not yet attracted any attention from students of the history of Oriental studies.

Fabricius had received most of the information provided in this book during his studies with Golius, ${ }^{43}$ and its content and structure can give valuable insight into the teaching of this influential patron of Arabic studies. This publication too was a textbook, and its primary aim, Fabricius declares, was to facilitate and propagate the learning of Arabic in Germany. The anthology was intended to complement the sparse text material available in the mid-seventeenth century. ${ }^{44}$

The first text in it was taken from a 'celebrated monument of Arabic belleslettres, ${ }^{45}$ the first of al-Harīî̀'s maqāmāt $(1054-1122) .{ }^{46}$ With this classical text, Fabricius's students were introduced to the Arabic 'stylus rythmicus', the rhymed and rhythmic prose, saj', which arguably found its finest expression in al-Harīī's maqāmāt. The text was also meant to provide the student with a model to follow in the composition of his own Arabic prose texts - a 'most accurate standard, straight as a rule' following which the students could compose their own orations, sermons, dissertations, and historical accounts or assess the style and the diction of others. ${ }^{47}$

42 J. Fabricius, Specimen arabicum quo exhibentur aliquot scripta arabica partim in prosa, partim ligata oratione composita, Rostock, 1638 . There is not much information available about the life and work of Fabricius (see fn 35). Some information is also given in the biography of one of his students in Danzig, Andreas Tscherning by H.H. Borcherdt, Andreas Tscherning. Ein Beitrag zur Literatur-und Kulturgeschichte des 17. Jahrhunderts, München and Leipzig, 1912.

43 See his grateful acknowledgment in the Praefatio ad Lectorem, sig., $4^{\mathrm{r}}$.

44 See also F. de Nave, Philologia Arabica. Arabische Studiën en drukken in de Nederlanden in de 16 e en 17de eeuw, Antwerp, 1986, 218-19.

45 G.J. Toomer, Eastern Wisedome and Learning. The Study of Arabic in Seventeenth-Century England, Oxford, 1996, p. 215.

46 J. Hämeen-Antilla, Maqāma, a History of a Genre, Wiesbaden, 2002.

47 ' $[\mathrm{V}]$ olui hanc elegantem Dissertationem publici juris facere, ut haberent Studiosi Linguarum exactissimam quasi amussim et normam, secundum quam et Orationes suas, Sermones, Dissertationes, Historias, etc. elegantissime conscribere, et ubi in alios Scriptores inciderint, de illorum stylo et dictione facile judicare poterunt.' Fabricius, Specimen, p. 167 . 
The second text was a qasida taken from the diw àn of early poems by the Syrian poet Abu'l-Alä' al-Ma'arrī (973-1057), which are collected under the title Saqt al-zand ('The Spark of the Fire Stick') and which show the influence of al-Mutanabbī. They are more conventional than the later poems collected under the title Luzüm mà là yalzam ('The Necessity of what is not Necessary'), or the Luzümiyyāt. These poems are unique in the history of Arabic poetry from the point of view of both content and form following an unusual rhyme scheme which uses two rhyme consonants instead of one. They were also remarkable for arranging each of the 113 chapters according to al-Khalil $b$. Ahmad's system of Arabic metres, covering almost all the metres established by al-Khalil in the eighth century ${ }^{48} \mathrm{~A}$ splendid manuscript of these poems, 'which, from the contradictions of the intelligible things deals with the vanity of the world and its contempt',49 had been acquired by Jacobus Golius and is still preserved at the Leiden University library. As we will see below, Golius published a 'Gnomologicum' from this collection. ${ }^{50}$

There are a number of manuscripts in the earliest Leiden collection of the third poem in Fabricius's Specimen. This is another example of the genre of poems rhyming in lām and is attributed to the famous Egyptian Sufi poet Ibn al-Fāriḍ (1181-1235). However, it is doubtful whether this love poem is authentic, as it belongs to the second part of Ibn al-Fāriḍs Dīwān, which had been added by his grandson 'Alī a century after the poet's death. The authenticity of the poems of the second part was first questioned by Arthur John Arberry, because they do not exist in the oldest manuscripts of the Diwwan and their style and content is often inferior to the first part of it. ${ }^{51}$

Fabricius printed all three poems verse by verse, with a literal, interlinear translation into Latin. Despite the obvious syntactic and stylistic shortcomings, which are repeatedly acknowledged by the authors, this form of literal parallel translation was common practice in Arabic textbooks before the appearance of

48 Cf. Y. Friedmann, 'Literary and Cultural Aspects of the Luzümiyyāt', in Studia Orientalia Memoriae D.H. Baneth Dedicata [editorial board, J. Blau et al.], Jerusalem, 1979, pp 347-65 '[E] contrario de intellectualibus rebus, et de vanitate mundi ac contemptu tractat', J. Golius, Arabicae linguae tyrocinium, id est Thomae Erpenii grammatica arabica ..., Leiden, 1656 , p. 227. LUL, MS Or. 100, cf. S.M. Stern, 'Some Noteworthy Manuscripts of the Poems of Abu l-'Alā' al-Ma'arrī', Oriens, 7, 1954, pp. 322-47, (339-44).

51 Cf. A.J. Arberry, The Mystical Poems of Ibn al-Färid, London, 1952. See for a recent assessment G. Scattolin, The Dīwān of Ibn al-Fārị. Readings of its Text Throughout History, Cairo, 2004, particularly p. 14. Our poem is printed in this edition on page 230 (Arabic counting). 
Golius's Arabic - Latin lexicon in $1653 .{ }^{52}$ For the same reason, the text material in these early textbooks is usually heavily annotated, with lexicographical and grammatical comments to almost every single word. In Fabricius's book we also find an alphabetically ordered index of Latin verbs, nouns and particles, which would refer to one of the lexicographical commentaries to Arabic words and which could thus be used as a Latin-Arabic dictionary.

The grammatical and lexicographical annotations frequently also contain translations of certain words and sayings into German and a number of learned comments on cultural and religious phenomena. In a note to the noun al-jam' ('congregatio), Fabricius not only provides the root of the word and some derivations but also inserts a detailed disquisition on the form and practice of the Friday prayers $\left(\right.$ jum' $\left.^{\prime} a\right) .{ }^{53}$ The annotation to the term șahfa - șiha $\bar{f} a$ ('patina', 'scutella', 'paropsis') and its derivation șahiffa give rise to a short essay on Arab paper, its production from the cotton of the gossypium, rather than from skin or linen as in Europe - hence its name 'charta gossypina' - and on Arab scribes, the reasons for the prohibition of printing, on the legendary collections of Oriental libraries - about which he had heard Golius talking many times - and the Muslim veneration for inscribed paper. ${ }^{54}$ There is a remarkable commentary on the Islamic prohibition of drinking wine, ${ }^{55}$ on chess, ${ }^{56}$ on the city of Basra, and on the use of camels in the Arab and Turkish world, in which Fabricius discusses the virtues and qualities of this animal and wonders why it has not yet been introduced into Germany. ${ }^{57}$

What makes the book a particularly valuable contribution to the history of Arabic scholarship is not only its edition and translation of poems from three classical Arabic authors but also its two pioneering essays on the nature and merits of Arabic oratory and of Arabic poetry. ${ }^{58}$

The first essay, Judicium de soluto dicendi genere arabum proprio (On the genre of the prose style of speech proper to the Arabs $)^{59}$ deals with Arabic prose

52 See for example in Erpenius's Historia Josephi Patriarchae, sig. Div .

53 This disquisition later is taken up by Hottinger in his Historia Orientalis and heavily criticised by Echellensis for some linguistic inadequacies. See my 'Johann Heinrich Hottinger and the "Historia Orientalis"', Church History and Religious Culture, 88.2, 2008, pp. 169-203 $(170-1)$.

$54 \quad$ Fabricius, Specimen, pp. 43-4.

55 Fabricius, Specimen, pp. 61-3. Fabricius contrasts the Arabs' abstinence with European habits of binge drinking and its dangerous consequences for society and health.

56 Fabricius, Specimen, pp. 143-4.

$57 \quad$ Fabricius, Specimen, p. 76.

$5^{8}$ A short assessment of these essays is already provided in my 'Divine poetry?', pp. 466-7.

59 Fabricius, Specimen, pp. 161-9. 
and rhetorical writing. In the first part the essay is a rehabilitation of the Arabs' frequent use of figurative speech with reference to classical rethorical theories. Although they like to adorn their speeches with metaphors, hyperboles and different figures of speech, 'they do not stop being good orators'. For, Fabricius argues with reference to classical examples and rhetorical theories, there is not just one simple nature of orators; one might flow and overflow, whereas another one tries to speak briefly and concisely; a fine, dry and sober one likes a certain simplicity of speaking, while another one likes to indulge in a rich, splendid and florid oration. ${ }^{60}$

The Arabs not only tend to use a figurative style in their prose writing, but also have a predilection for rhymes, Fabricius writes. On this he elaborates in the second part of his essay, which is a short introduction to the Arabic tradition of rhymed writing and of saj. With al-Harīin's first maqäma, Fabricius had presented an outstanding example of this genre and, in order to support his student's understanding and appreciation of this important stylistic form, Fabricius inserted a transliteration of the first four rhymes. ${ }^{61}$ The transliteration also illustrated the fact that, in the Arabic tradition of rhymed prose writing, the periods and verses could be of uneven length, whereas classical Arabic poetry was bound by strict metres. ${ }^{62}$

It was to these metres that Fabricius dedicated the second essay in his Specimen arabicum, the Coronis de poësi aut metrica ratione in genere, et arabicae linguae propria. ${ }^{63}$ This is the first substantial account of the classical system of Arabic prosody to be printed in Europe. ${ }^{64}$ In it, Fabricius argued that the poetical or metrical form of speech was older than prose and that it was a universal phenomena, esteemed by every nation and culture. 'However', Fabricius says, 'I do not know whether there has ever been a nation that was as dedicated to poetry as the Arabs are, who seem to be born just for this art.' ${ }^{35}$ One of the most remarkable aspects of Fabricius's essay on Arabic prosody

60 'oratorum [...] non simplex, non una natura est, sed hic fluit et redundat: contra ille breviter et circumcise dicere affectat: tenuis quidam et siccus et sobrius amat quandam dicendi frugalitatem; alius pingui et luculenta et florida oratione lascivit.' Fabricius, Specimen Arabicum, p. 164.

$61 \quad$ Fabricius, Specimen, p. 167.

62 Fabricius, Specimen, p. 168.

63 Fabricius, Specimen, pp. 169-82.

64 On the unpublished treatise De arte metrica by Leo Africanus see fn. 34. Nothing noteworthy is found in Kirsten's Grammatices arabicae liber I, sive orthographia et prosodia arabica, Breslau, 1608, mentioned by Toomer, Eastern Wisedome, p. 226.

65 'Haud tamen scio, an ulla unquam gens aeque dedita fuerit Poesi, quam Arabes, qui certe ad artem hanc nati propemodum esse videntur.' In support of this view, Fabricius quotes the passage from Leo Africanus which is mentioned in fn. 2, cf. Specimen, p. 175. 
is his awareness and his exposition of fundamental differences between the Arabic metrical system, in which the syllable does not play a role as a metrical element, and the Latin and Greek tradition:66 'Arabs divide the syllables and vowels not after the manner of the Latins, Greeks and Hebrews. The metre depends only on the succession of moving [i.e. vocalized] and quiescent [unvocalized] consonants.' ${ }^{67}$ The difference between a 'moving', i.e. vocalized letter or consonant (harf mutaharrik), and a 'quiescent' consonant which is not followed by a vowel (harf sākin) is clearly explained by Fabricius as is their significance as the basic elements of the Arabic metrical system. He also acquaints the European reader with the metaphorical terminology the Arabs used in describing the constituent parts of their verses: a verse is called tent or house (bait) 'as if it were a perfect metrical structure or a complete building' ('quasi perfecta metri structura, aedificium absolutum.'). With a verse by al-Macarrī Fabricius illustrates how every verse consists of two hemistichs. Each verse or hemistich is composed by what Fabricius calls 'cords' ('chorda'; sabab, pl. asbāb) and by 'pegs' ('palus'; watid, pl. awtād). Pegs and cords denote a standardized combination of two or three vocalized or unvocalized consonants, which are then combined into different metrical feet (called juz', ajz $\hat{a}^{\prime}$ - i.e. 'parts'). These different feet again are combined and form the different metres which, in the classical account of al-Khalil b. Ahmad, are distributed in five circles. ${ }^{68}$

Fabricius's Specimen arabicum is not only a remarkable attempt to convey the main features of Arabic poetry to the European reader. It is also an impressive attempt to spread the study of Arabic beyond the few centres of Arabic learning by providing a multifaceted textbook for the teaching of Arabic at Rostock and at other German universities.

We know of at least one student who had put the knowledge of Arabic that he had learned from Fabricius in Rostock to some use: the Silesian poet and friend of Martin Opitz, Andreas Tscherning (1611-1659). ${ }^{69}$ Like Opitz, Tscherning was born in the then German town of Bunzlau (today Bolesławiec,

66 I was introduced to Arabic metrics by Wolfhart Heinrich's Poetik, Rhetorik, Literaturkritik, Metrik und Reimlehre in Grundriß der arabischen Philologie. Vol. 2: Literaturwissenschaft, ed. H. Gätje, Wiesbaden, 1987, pp. 177-207. I still find this one of the most accessible introductions to the subject.

67 Fabricius, Specimen, p. 177.

68 Ibid., p. 182.

69 We are remarkably well informed about the life and work of Andreas Tscherning thanks to the biography by Borcherdt, Andreas Tscherning. 
Poland). ${ }^{70}$ During a short period, between 1635 and 1636, he was in Rostock and took private Arabic lessons from Fabricius. ${ }^{71}$ According to his own account they used Golius's 1629 textbook with 'Ali's proverbs and the Lämiyyat al-'ajam. ${ }^{72}$ During his time in Rostock and later in Breslau, Tscherning started to prepare a Latin-German translation of the proverbs in Golius's edition. In 1639 he tells Opitz in a letter that he had tried to have the proverbs printed in Rostock, where, as we have seen, an Arabic printing press had been set up in the late thirties. ${ }^{73}$ Opitz discussed this with Fabricius, who was then back in Danzig and who seems to have been confident that he would find a publisher for Tscherning's Arabic booklet in either Rostock or Leiden. So, on 15 July 1639, Opitz asked Tscherning to prepare a copy for print and send it to him. ${ }^{74}$ Why Fabricius finally tried to have Tscherning's multilingual edition of 'Ali's proverbs printed in Leiden rather than in Rostock is not known, but, according to Tscherning's preface, Fabricius lost the copy in a shipwreck on his way to Leiden. ${ }^{75}$ However that may be, Tscherning decided to have the Latin - German translation Centuria proverbium Alis imperatoris Muslimici distichis expressa published in Breslau without the Arabic characters. These proverbs came out in 1641, but are usually bound together with the 1642-edition of his Deutscher Getichte Früling. It is most probably the first, and without doubt the most extensive, German translation of an Arabic text to be published so far. The work gives a literal Latin translation of each proverb, followed by metrical Latin and German renderings and a Latin commentary, in which Tscherning often refers to similar examples from antiquity and from the Erpenius edition. ${ }^{76}$

Tscherning's contemporaries were excited. Johannes Mochinger in Danzig compared him with Opitz and suggested that he now move to even greater

70 Martin Opitz. Briefwechsel und Lebenszeugnisse, ed. K. Conermann, Berlin and New York, 2009, p. 1273.

71 Borcherdt, Andreas Tscherning, pp. 41-50. See also the informative entry 'Andreas Tscherning' in the Catalogus professorum Rostochiensium, <http://cpr.uni-rostock.de/meta data/cpr_person_00001407> (26/3/2015)

72 Cf. A. Tscherning, Centuria proverbiorum Alis imperatoris muslimici distichis Latino-Germanicis expressa, Breslau, 1641, preface.

73 Conermann, ed., Martin Opitz, n. 390618 ep, pp. 1562-5.

74 Conermann, ed., Martin Opitz, n. 390715 ep, pp. 1575-82.

75 Tscherning, Centuria proverbiorum Alis, preface.

76 See Borcherdt's critical assessment of the translation and the commentaries, Borcherdt, Andreas Tscherning, p. 78 . 
tasks and deliver in print what Erpenius once promised - the poems of al-Mutanabbī. ${ }^{77}$

In the year following the publication of this 'Arabic booklet' Tscherning returned to Rostock with the financial support of Matthäus Apelt (Apelles von Löwenstern) and continued his studies. ${ }^{78}$ In 1644 , the University of Rostock offered him the professorship of poetry, and in 1646 he had a reprint of his Deutscher Getichte Früling published by the printing house of Johann Richel. In this reprint too, Tscherning's collection of his own German poems was completed by 'Ali's proverbs, this time, however, together with the Arabic text. Nor was this the end of Tscherning's efforts to make the Arabic language and belleslettres known in Germany. Almost ten years later, in 1654, he published another German translation of a collection of Arabic proverbs. ${ }^{79}$ This time, he seems to have exploited Erpenius's textbook of 1615 from which he copied more than sixty Arabic proverbs with their Latin translation, to each of which he added a metrical German translation. ${ }^{80}$

The poetical work of Andreas Tscherning is one of the earliest examples of German literature inspired by Arabic poetry. Together with the publication of Johann Fabricius it is a remarkable testimony to the enormous sphere of influence which the Leiden school of Arabic, under the patronage of Thomas Erpenius and Jacobus Golius, had on Northern Europe. ${ }^{81}$ We have already seen

77 Tscherning, Centuria proverbiorum Alis, preface. See Borcherdt, Andreas Tscherning, p. 78 .

78 Conermann, ed., Martin Opitz, p. 1274.

79 Proverbia arabica, germanice expressa, ab Andrea Tscherningio, Prof. Poëtices, Rostock, 1654 .

80 At the moment, I can only speculate about the reasons for the significant differences between Tscherning's edition and Erpenius's (the number of proverbs, their arrangement, some additions which are not in Erpenius etc.). Tscherning may have based his edition on an incomplete manuscript copy.

81 Further evidence for this, which has not yet received much scholarly attention, is a book by Jakob Gerschow from Greifswald, in which the proverbs from Erpenius's 1615 edition are translated into Latin distichs, the Proverbiorum arabicorum, distichis latinis expressorum, 100 academicorum apodemicorum, albis inscriptorum centuria Locmannica, consecrata illustrissimo Crojorum Duci Ernesto - Bogislao, à Jacobo Gerschovio philoglotto. Exemplar geminis arabum literis extat Leydae, ex editione Thomae Erpenij 1615... Greifswald, 1635. Borcherdt, Andreas Tscherning, speculates that Gerschow's work was an inspiration for Tscherning and that his German distichs were, at least partly, influenced by Gerschow's. 
that the knowledge of the Arabic metrical system, as well as the text material, the translations and most of the grammatical and linguistic commentaries to the poems in the first part of the book, were not the result of Fabricius's own studies but were derived from the lectures of Golius he had attended in Leiden: 'I owe all my knowledge about this language to Golius', Fabricius says in his book. ${ }^{82}$ Golius himself favourably referred to Fabricius's publication in the preface to the 1656 edition of Erpenius's grammar, to the reading matter of which he also added two texts already published by Fabricius: the first maqāmā of al-Ḥarīī and the verses from al-Ma'arrī's Saqțal-zand. ${ }^{83}$ These complemented the other texts - including the fables of Luqman and the sententiae from the $16{ }_{3} 6$ edition, three Qur'anic suras (Luqmān, al-Ṣaf and alSajda) and the sermon by Eliya III that had already been published in Golius's first publication of 1629. As in this textbook, Golius added a number of single verses from different poets, among them again three verses by al-Mutanabbī. This was a fine selection of text material, which covered a number of different text sorts and literary and poetical genres. Starting with the short proverbs and adages, the teaching moved to examples of prose and poetry, selected 'from writings which the Arabs themselves praise as constituting the genuine and sincere form of Arabic.' 84

Some of the Latin translations were based on classes given twenty years previously, during the time of Fabricius's stay in Leiden. Because of the existence of a lexicon, the literal translation as well as a great part of Fabricius's annotations to al-Harīī and the verses from al-Ma'arrīs Saqt al-zand were obsolete and were replaced by a smoother translation and more detailed information about the historical, cultural and biographical background of the two poets. ${ }^{85}$ The three texts at the end of the book - proverbs and sayings, verses of different lengths from different poets, a short Qur'an sura (al-Sajda) and a qasida from al-Ma'arrì's Luzümiyyāt - were only printed in Arabic. Here the students were confronted with a higher level of difficulty and they could apply their acquired knowledge of Arabic without the guidance of a Latin translation and grammatical commentaries.

82 '[C]ui omnem hujus linguae cognitionem meam asscribo atque acceptam refero.' Fabricius, Specimen, p. 170.

83 It was already noted by Wilhelmina Juynboll's in her thesis Zeventiende-eeuwsche beoefenaars van het Arabisch in Nederland, Leiden, 1931, pp. 148-9, that Fabricius' anthology was a source for Golius' work. I owe this reference to Dr Arnoud Vrolijk.

84 ' [...] ex iis quidem scriptis, quibus genuini et synceri Arabismi laudem tribuant Arabes ipsi.' Golius, Tyrocinium, p. 174.

85 See for instance the neat but informative introduction to the life and work of Abū l-'Alä' al-Ma'arrī on pp. 226-27. 
Golius's 1656 edition is by far the most comprehensive and the most didactically accomplished version of Erpenius's grammar ever to appear. All evidence points to the fact that the reading and translation of Arabic poems was an essential component of Golius's teaching. This also included the study of their metrical structure, as we can gather from a manuscript in the collection of Narcissus Marsh at the Bodleian library. The Mensura carminum omnium adaptata ad normam Prosodiarum Graecae et Latinae are dated 22 February 1654 and give the 'canones and mensura' according to which all Arabic poems have to be composed and examined. ${ }^{86} \mathrm{~A}$ number of tables offer a symbolic representation of the formal patterns of fifteen basic Arabic metres, with all the possible variations and derivations. The tables were most probably used as instruction material for Golius's teaching of Arabic metrics. He refers to his teaching in the preface to the grammar and deplores the fact that his prosody could not be printed 'because of the state of our town, and public and private reasons that came together. ${ }^{87}$ The adaptation to the classical prosody, which is indicated in the title of the manuscript, is achieved by the use of familiar symbols $(-$ and $U$ ) for long and short syllables and by the use of classical terminology to describe the metrical feet ('spondaeus', 'anapestus', 'jambus' etc.).

The teaching aides and textbooks which Golius composed were widely used in classrooms all over Europe. We know that Edward Pococke, the Laudian Professor of Arabic at Oxford, used the material provided by Golius extensively in his teaching. P.M. Holt, in his unpublished thesis on Edward Pococke's Arabic Studies, has discovered and transcribed a number of lecture notes. When he began teaching in 1636, Pococke used Golius's 1629 textbook with 'Ali's proverbs, and al-Ṭughrāî̀'s Lammiyyat al-ajam, and he continued to do so in the following years. ${ }^{88}$ After its publication in 1656 , Pococke used the Tyrocinium

86 Bodl. Oxf., MS Marsh 42, fols $166^{\mathrm{r}-61^{\mathrm{v}}}\left(161^{\mathrm{v}}\right)$.

87 '[D] ecretum mihi erat aggregare ad Grammaticam Annotationes, \& conceptum à me, qui hactenus defuit, de Arabum Prosodia tractatum: quorum partem jam ante complures annos auditoribus meis communica[ve]ram. Sed praesenti urbis nostrae statu, tum publicae tum privatae inciderunt causae, quae illud meum \& Typographi propositum pro hoc tempore abrumpunt \& sistunt; prima quam nobis Deus concesserit opportunitate exsequendum', Golius, Tyrocinium, sig. ${ }^{*} 2^{\mathrm{r}}$. See also the short metrical notes and the reference to his prosody on page 229, at the beginning of Abu l-'Alā"s poem. 'Metro carminis Copiosi [al-wāfir], ita ceu proprio dicti nomine, \& quidem generis primi, Consonantiâ autem consequente \& mobili. De quibus consule Prosodiam.'

88 Bodl. Oxf., Ms Poc. 424 contains lecture notes by Pococke on the grammar of these proverbs; Ms Poc. 425 also contains lecture notes on proverbs with references to Erpenius's Rudimenta Linguae Arabicae, but they are in the hand of a student. See Toomer, Eastern Wisedome, p. 215 and Holt, Studies in the History of the Near East, p. 6. 
and taught the new reading material provided in it. For the instruction of the more advanced students, Pococke lectured on verses by Abū l-'Alā' and on the first maqāma by al-Harīrī, 'cui primas - post Alcoranum suum - eloquentiae laudes et summa elogia tribuunt Arabes'. 89

Here too, the choice of poetical texts was motivated by their contribution to the standards of Arabic eloquence and literature and, accordingly, Pococke's teaching was mainly focused on linguistic aspects. The poem he chose for the instruction of students in Arabic was the Carmen Tograi, which Pococke honoured with a new fully vocalized edition, a new translation and an extensive apparatus of grammatical and lexicographical notes in 1661. This publication, again, was a textbook that should make the 'attainment of the Arabic tongue easier to those who study it. ${ }^{90}$ In particular, the new translation was received with critical acclaim in the Republic of Letters; 'Everything from Pococke is perfect. This excellent man understands the Arabic language à fond and the translation of this poem is unsurpassable.91 Pococke's edition and his translation were still used more than a century later when the judicious German Orientalist Johann Friedrich Hirt printed it in his Anthologia Arabica. ${ }^{92}$

The great bulk of Pococke's book consists of annotations that sum up the lectures he had regularly delivered on this poem. ${ }^{93}$ Here Pococke provided a detailed semantic and grammatical analysis of almost every single word of the poem, often adding phrases and idiomatic expressions as well as Hebrew cognates. His comments often refer to the lexicons of al-Jawharī and al-Fīrūzābādī, and the commentaries on the poem of al-Ṣafadī and al-Damāmīnī. ${ }^{94}$ Only occasionally does Pococke deal with matters of other than grammatical interest - a neglect that was later criticized by Reiske. ${ }^{95}$ At the end of the book, Pococke

89 Some lecture notes to al-Ḥarīī are preserved in Ms Poc. 427 fols 110, 227-32, and Ms Poc. 428, fols 1-2. Cf. Holt, Arabic Studies, p. 108. The use of Abū l-'Alā"s poem can be inferred from the title of a printed sheet from 1673, which is indicated by Madan, Oxford Books, vol. 3, Oxford Literature 1651-1680, Oxford, 1931, p. 276. Cf. Toomer, Eastern Wisedome, p. 214.

9o L. Twells, 'The Life Of ... Edward Pocock', in The Lives of Dr. Edward Pocock ... Zachary Pearce ... Thomas Newton ... And Philip Skelton, ed. A. C., London, 1816, vol. 1, p. 248; Holt, Studies in the History of the Near East, pp. 16-17.

91 'Alles, was von Pocoken gekommen, ist vollkommen. Dieser vortreffliche Mann verstund das Arabische aus dem Grunde. Seine Übersetzung von unserm Stücke ist unverbesserlich', Reiske, Thograi, pp. 24-5.

92 Hirt, Anthologia Arabica, pp. 119-37.

93 The text and the translation of the poem make up 20 pages, the notes more than 200.

94 See Holt, Arabic Studies, p. 66.

95 'Nur wünschte ich, daß seine Anmerckungen nicht so trucken, und bloß grammaticalisch, sondern mehr philologisch seyn, das ist, den Sinn des Dichters, die Geschichte und 
put together an alphabetical index of all Arabic words explained in the notes. This index could serve as a dictionary to the students who did not have access to Golius's lexicon. ${ }^{96}$ With regard to the history of Arabic scholarship, two more elements of this publication are to be noted: the introduction by Pococke and the comprehensive and detailed Tractatus de prosodia arabica by his favourite student Samuel Clarke, which was bound together with the Carmen Tograi but published with a separate title page. Clarke's account surpassed by far the ones of his predecessors in clarity, perspicuity and comprehensiveness. The treatise facilitates the understanding of this difficult matter with its systematic composition and the clear presentation of the material. The work also excelled in drawing upon a number of classical Arabic treatises on the subject. Apart from the Qașida al-Khazrajīya, which had already been made known by Guadagnoli, ${ }^{97}$ Clarke exploited al-Jawharìs 'Arüd al-waraqa, and, most importantly, al-Zamakhsharì's al-Qisțās al-mustaqìm fí 'ilm al-'arüd. His treatise starts with a chapter On Letters and Syllables, which describes the basic elements of Arabic metrics. This is followed by a chapter On Feet (De pedibus) and On the Classes of Poems (De carminum generibus) in which the formation and nature of the five circles of al-Khalil's classical metrical theory are explained. As opposed to Fabricius, Clarke, in Chapter v, De pedum mutationibus, gives a full account not only of the ideal metrical forms (bahrr, pl. buhür), but also of the different forms of deviations (zihâff, pl. zihafät and 'illa, pl. 'ilal) which appear in the actual performances of these metres. Chapters vI to XXI are probably the most remarkable part of the book and aim to provide a very practical understanding of Arabic prosody. Here Clarke follows closely al-Zamakhsharī who, in his al-Qistâs al-mustaqim, presents one example from the stock of classical Arabic poetry for every normal pattern of the sixteen metres, as well as for all the major variations. Al-Zamakhshari dissects the examples into their metrical feet and he provides the scansion of every verse, all of which is repeated by Clarke. However, Clarke's own mastery of Arabic metrics is evidenced by the fact that he not only adheres closely to his source material, but also applies the theory independently. The students and readers of his book are given a full metrical analysis of the Carmen Tograi in Chapter viII, dedicated to the metre

Sprichwörter, darauf er anspielt, in ein heller Licht setzen möchte.' ['I would wish that his annotations were not so dry and not only grammatical, but also philological, so that they would shed a light on the intention of the poet, and on the stories and the sayings he refers to.'] Reiske, Thograi, p. 25.

97 Clarke was planning to edit and translate the text. However, this project came to nothing. See Toomer, Eastern Wisedome, p. 226. 
al-bașit, and a discussion of its rhyme scheme in the last chapter of the book, De rhythmo. ${ }^{98}$

Clarke's treatise was unsurpassed until the second half of the eighteenth century and it marks the peak of a seventeenth-century scholarly tradition, which I have tried to describe in the preceding pages. This first generation of Arabic scholars used Arabic poetry mainly for teaching purposes and hence they were mainly interested in the grammatical, lexicological and formal aspects of Arabic poetry. This didactic tradition was underpinned by the topos of the legendary beauty and the cultural, mythological and linguistic significance of Arabic poetry, which had found popular expression in Erpenius's Oration on the Value of the Arabic Language and other works of this kind. It was also the commonplace with which Pococke opened his inaugural lecture on 10 August 1636 and it lies at the heart of the praelectiones to the edition of the Carmen Tograi. ${ }^{99}$ The Arabs, Pococke says there, would see themselves as a nation of poets that, since the beginning of time, has been cultivating poetry to its highest level and they would judge their poetical tradition to be far superior even to that of the Greeks and the Romans. Moreover, Pococke goes on, the 'Arabum magistri' would claim that their language was derived directly from Adam, that it was God's own language, spoken by those admitted to Paradise and used as the language of the Qur'anic revelation. ${ }^{100}$ To cultivate and preserve the original purity of their language, Pococke says, was every Arabic poet's first and foremost aim. Poetry among the ancient Arabs had the same function as writing: the preservation and memory of genealogies and myths, and, above all, of a pure and unaltered language. Arabic poetry, Pococke concluded, would thus be an encyclopedia of the Arabs' knowledge, an archive of their culture, their wisdom and their original language. ${ }^{101}$

98 The metre is discussed on pp. $62-5$, the rhyme on p. 153 .

99 According to the short excerpt from Pococke's inaugural lecture from 1636, which is inserted after the notes to the Carmen Tograi on a page that would otherwise have been left blank and which gives an idea of the Arabs' esteem for their poetry. Pococke, Carmen Tograi, sig. ${ }^{*} 3^{\mathrm{v}}$.

101 'Arabic Poems were encyclopedias and collections of their wisdom, a treasury in which they stored all the valuables of their language, a cornucopia, from which they sought all the things that contribute to practice and embellishment, an oracle, from which they sought the solution of all controversies which could arise from things or from words.' Pococke, Carmen Tograi, sig. ${ }^{*}{ }^{\mathrm{v}}$. 
The idea that poetry functions as a cultural memory, that it treasures and reveals ancient myths and the opinions and cultural values of nations, became a central idea to scholars of the eighteenth and early nineteenth centuries. It was taken up and cultivated by one of the most influential - and also most controversial - Arabist of the next generation, the Dutch 'Interpres Legati Warneri' Albert Schultens (1686-1750). In the work of Albert Schultens and his students, Arabic poetry became an etymological archive that would lead to the original and essential meaning of the Sacred Scriptures of the Old Testament. This argument triggered an unprecedented scholarly interest in Arabic poetry and a number of editions and translations of Arabic poems, together with translations and etymological and philological annotations in Northern Europe. However, this is a story I am telling elsewhere. ${ }^{102}$

102 See my 'Language of Paradise’. 